\title{
The Relation Among Neck Pain, Modic Changes and Uncal Degeneration: An MRI Study
}

\author{
(1) Muhittin Emre Altunrende, 슬 Elif Evrim Ekin²
}

\author{
'Department of Neurosurgery. \\ Gaziosmanpaşa Taksim Training and \\ Research Hospital, İstanbul, Turkey \\ ${ }^{2}$ Department of Radiology, \\ Gaziosmanpaşa Taksim Training and \\ Research Hospital, İstanbul, Turkey \\ Submitted: 16.02 .2019 \\ Accepted: 03.04.2019 \\ Correspondence: \\ Muhittin Emre Altunrende, \\ GOP Taksim Eğitim ve Araştırma \\ Hastanesi Beyin ve Sinir Cerrahis \\ Kliniği, İstanbul, Turkey \\ E-mail: mealtunrende@msn.com

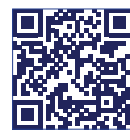 \\ Keywords: Cervical \\ degeneration; Modic changes; \\ neck pain; uncal degeneration. \\ This work is licensed under a Creative Common \\ Attribution-NonCommercial 4.0 International License.
}

\begin{abstract}
Objective: The present study aims to investigate the correlation of neck pain with Modic changes and uncal degeneration. Our secondary goal is to investigate the relationship among Modic changes, disc herniation and uncovertebral joint degeneration in the cervical spine.
\end{abstract}

Methods: In this study, patients with a presenting symptom of neck pain were evaluated. We have excluded patients with spinal and cervical mass lesions, spinal fracture and history of cervical vertebral operation. Pain evaluation was made using the Visual Analog Scale (VAS) at rest. The cervical vertebral MRI and X-ray were used for radiological evaluation. In these scannings, loss of cervical lordosis, uncal degeneration, Modic changes and intervertebral disc degeneration were recorded.

Results: The findings showed that Modic changes were more frequent in patients with disc hernia compared with patients without disc hernia $(p<0.00 \mathrm{I})$. The uncal degeneration was significantly more frequent in patients with Modic changes than in patients without Modic changes $(p<0.00 I)$. The VAS scores were not associated with Modic changes $(p=0.919)$.

Conclusion: The disc herniations and uncal degeneration are related to Modic changes in the cervical spine. The neck pain was not associated with Modic changes, which may arises from the study population with mostly chronic neck pain. Recommendations are provided to investigate a new large cohort study in the patient with acute pain.

\section{INTRODUCTION}

Spinal degeneration and back pain is an important health problem in a lifetime for the human being because of the bipedalism. Many studies are conducted by several clinics who are working on spinal diseases to understand spinal degeneration. As a result of these studies, there have been classifications and algorithms concerning this subject. According to the literature, degenerative, vertebral endplate changes, also known as Modic changes, are the most common classification to evaluate vertebral degeneration, which have been first described by Modic et al. ${ }^{[I]}$ among patients with chronic back pain. In recent years, Modic changes have been classified into three groups according to the signal changes in magnetic resonance imaging (MRI). Modic Type I changes are described as the bone marrow edema and inflammation. Modic Type 2 changes are described as the displacement of red bone marrow with the fatty bone marrow due to ischemia. Modic Type 3 changes are described as a hypointense line consistent with subchondral sclerosis. ${ }^{[2]}$ Modic changes are a dynamic indicator of age-dependent degeneration and may vary in between these types during the natural course of the disease. ${ }^{[3]}$ Therefore, the co-occurrence of Type I-2 and Type 2-3 have been defined in the literature. ${ }^{[4]}$ In parallel with, the prevalence of Modic changes increases with advancing age. ${ }^{[1,3]}$ Modic changes are generally seen with adjacent vertebral disc degeneration. ${ }^{[3]}$

Modic changes were first described in the lumbar vertebrae and generally investigated in the lumbar region in the literature, which can be seen in patients with chronic lumbar pain with a frequency of $19-59 \% .^{[1,2,4]}$ In the lumbar region, type 2 changes are encountered as the most frequent; type 3 changes can be encountered as the least frequent. Also, the most affected segments are the most mobile levels, which are L4-5 and L5-SI. ${ }^{[1,4,5]}$ In the literature, there are some studies investigating the relationship between the Modic changes and pain. Kjaer et al. ${ }^{[6]}$ stated the obvious relationship between the clinical symptoms 
and degenerative disc diseases in the lumbar spine and claimed that the clinical symptoms are more related to the disc degenerations with the occurrence of Modic changes.

The prevalence of cervical Modic changes are rarely being investigated in the literature. In this study, our aim is to evaluate the association of the Modic changes with the other cervical spondylosis findings and to investigate the compatibility of the Modic changes with cervical pain, which have been poorly studied before.

\section{MATERIALS AND METHODS}

In this prospective study, after getting approval from the ethical committee Taksim Training and Research Hospital on 27.01.2016/53, 450 patients with neck pain were evaluated between February and December 2016. One hundred four patients were included in this study who could perform a VAS test properly. The cervical spondylosis was investigated in the cervical vertebrae $X$-ray and cervical $M R I$ in seven days after the clinical performed. Patients with infiltrative bone marrow diseases, spinal masses, infectious and inflammatory spondylitis, vertebral fractures, ArnoldChiari malformation, a history of cervical surgery, existence of artifacts in the MRI were excluded from this study.

Visual Analog Scale (VAS): VAS at rest, that was used in our study is a standard $10 \mathrm{~cm}$ straight line starting with 'no pain' ending with 'insupportable pain' horizontally. After explaining the essential points of VAS to the patients, they were asked to mark the appropriate point on the line in concordance with the pain severity. Patients marked the appropriate point on the line indicating the severity of the pain. The longitude between the starting 'no pain' point and the point patients have marked was measured in centimeter $(\mathrm{cm})$ and noted for each patient.
MR imaging: I.5Tesla MR (SignaHDxt; General Electric) imaging machine and whole-body coil was used. For the cervical evaluation sagittal TI-weighted fast spin-echo (FSE), T2-weighted FSE and axial T2-weighted FSE (3680/I28 repetition time/echo time, I80x256 matrix, $280 \mathrm{~mm}$ field of view and $4 \mathrm{~mm}$ section thickness, NEX2 were used.

Radiological evaluation: In cervical MR imaging evaluation, Miyazaki's grading system was used for the disc degeneration and disc hernias. ${ }^{[7]}$ High grade (grade 4-5) vertebral discs which have decreased height of the vertebral body and hypointense homogenous disc herniation were noted. Furthermore, loss of cervical lordosis and degeneration of the uncovertebral joint was investigated in the cervical X-ray and MRI. Modic changes ${ }^{[2]}$ (type I: TI-W hypointense, T2-W hyperintense signal, type 2: TI-W hyperintense, T2-W iso to hyperintense, type 3: TI-W and T2-W hypointense signal) were used to evaluate vertebral end-plate degeneration (Figs I, 2).

Patient evaluation for the VAS scoring was made by the neurosurgeon (MEA) and MRI evaluation was performed by the radiologist (EEE) who are well-experienced in spine disorders. Both the neurosurgeon and the radiologist was blinded for the alternate examination. Results were emerged together after the completed of the examination.

Statistical analysis: The normality of the distribution was analysed using Kolmogorov Smirnov (One sample Kolmogorov-Smirnov test) and Shapiro Wilk tests, Q-Q, boxplot and histogram graphics. Data were noted as mean, standard deviation, median (min.-max.), frequency and percentage. Categorical variables were evaluated with Fisher's exact test and Chi-squared test with Yates' correction. Quantitative variables that show the normal dis-
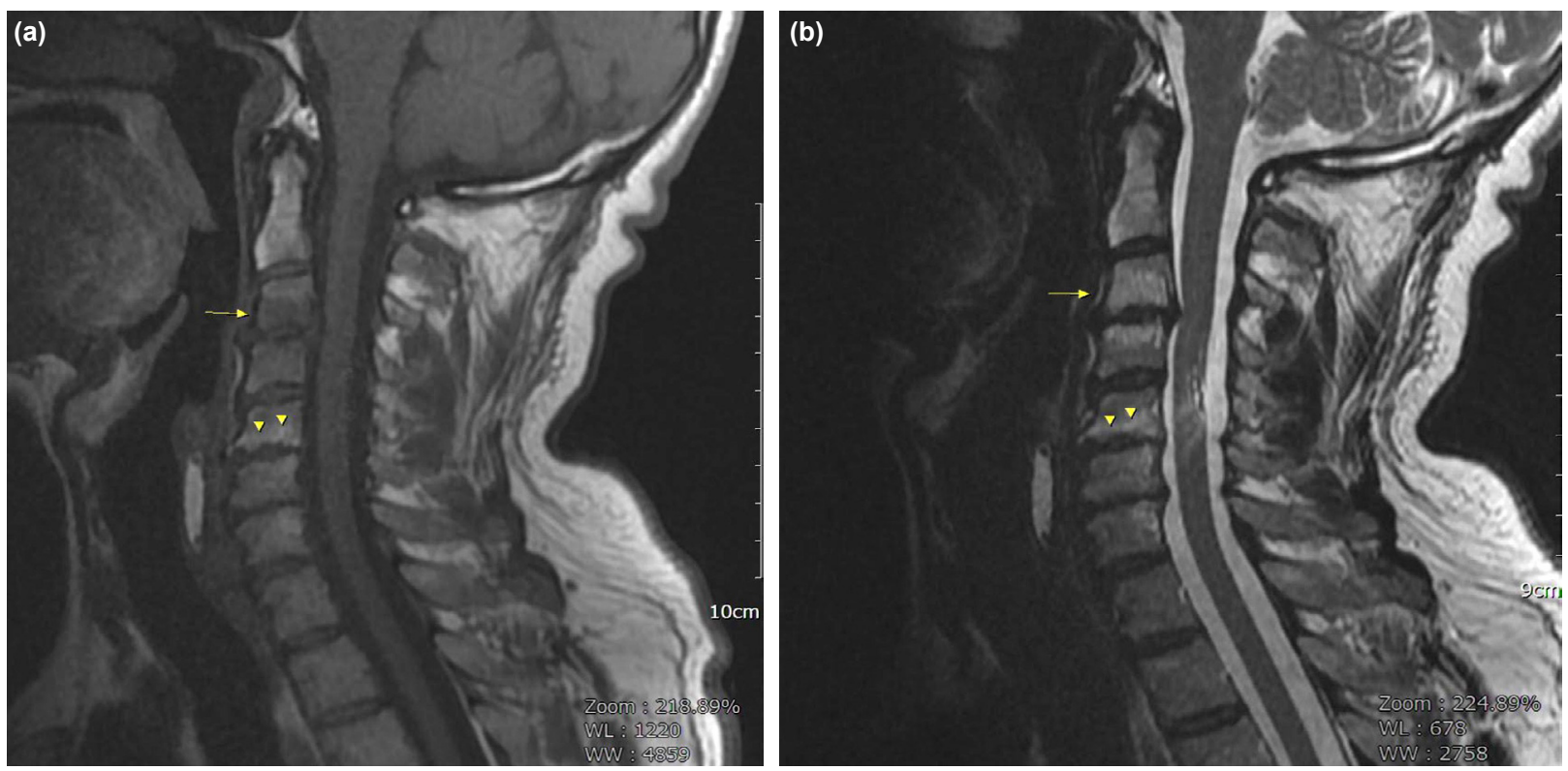

Figure 1. (a) MRI T1 weighted midsagittal image shows hypointens signal in the endplates adjacent to the C3-4 disc (long arrow), and hyperintense signal in the endplates adjacent to the C5-6 disc (arrow head). (b) MRI T2 weighted midsagittal image shows hyperintense signal on C3-4 (Modic Type1) and C5-6 end plates (Modic Type 2). 
tribution in independent groups were compared with the t-test (independent samples t-test), quantitative variables that show non-normal distribution were compared with the Mann-Whitney $U$ test. The compatibility of the disc herniation, $M C$ and uncovertebral degeneration with each other were determined using the Kappa test. Effects of disc herniation, MC and uncovertebral degeneration on the VAS scores were evaluated with univariate analysis of variance. The significance level was set to be $p<0.05$ (twotailed). The analysis was carried out using an NCSS 10 statistic package programme.

\section{RESULTS}

In our study, 450 patients were evaluated and after the exclusions, 104 patients' data were used for evaluation. Five segments for each patient resulting with 520 levels were investigated. The median age was found to be 41.5 (range, 16-74 years). 86 female and 18 male patients were included in this study. The gender related median age was 41 in females (range l6-73 years), whereas in males, it was 44 (range 26-74 years). Loss of cervical lordosis was encountered in 80 patients (76.9\%) among 104 patients.

Disc herniation was evident in 64 patients (61.5\%) among 104 patients. According to the evaluation of the disc herniation levels, in 64 patients disc herniation was noted in a total of II 3 segments. Disc herniation $(n=113)$ was evident mostly in C5-6 ( $n=45,39.8 \%)$, whereas it was evident at least in C3-4 ( $\mathrm{n}=11,9.7 \%)$. There was not any disc herniation noted to be at C2-3 level.

Modic changes was determined in 28 levels (5.38\%) among 520 levels. In 5 segments type I, in 20 segments type 2, in 3 segments type 3 , Modic changes was noted. Modic changes was mostly seen at $\mathrm{C6-7}(n=12)$ level, at least at C3-4 $(n=5)$ and C4-5 level $(n=5)$ (Table I). The median age of the patients with Modic changes was 54 (min 18 , max 74), whereas in patients without Modic changes, the median age was found to be 38 ( $\min 16, \max 72$ ). There was a significant difference as a means of age between the patients with Modic changes and patients without Modic changes $(p<0.001)$.

The frequency of Modic changes in a level with disc herniation $(24 \%)$ increased more than in a level without disc herniation $(0.25 \%)\left(\chi^{2}=92.5 ; p<0.001\right)$.

The frequency of uncal degeneration in the disc herniation segments $(60 \%)$ was a significant difference when compared to the without disc herniation segments (\%0.49) $\left(\chi^{2}=265 ; p<0.001\right)$.

The frequency of uncal degeneration in patients with Modic changes (89\%) was a significant difference when compared to the patients without Modic changes (9\%) $(\mathrm{p}<0.00 \mathrm{I})$.

Median pain period in patients with Modic changes was 23.7 months; in patients without Modic changes, but with other degenerative changes was 14 months. In all of the patients included in this study, the median value for VAS
Table I. Modic type of distribution according to the level intervertebral disc

\begin{tabular}{lcccc}
\hline Modic changes & C3-C4 & C4-C5 & C5-C6 & C6-C7 \\
\hline Type I $(n=5)$ & $n=1$ & $n=2$ & $n=0$ & $n=2$ \\
Type 2 $(n=20)$ & $n=4$ & $n=2$ & $n=4$ & $n=10$ \\
Type $3(n=3)$ & $n=0$ & $n=1$ & $n=2$ & $n=0$ \\
Total $(n=28)$ & 5 & 5 & 6 & 12 \\
\hline
\end{tabular}

Table 2. VAS comparison in patients with $\mathrm{DH}$ and $\mathrm{DH}+\mathrm{MC}$

\begin{tabular}{lcc}
\hline & VAS median value & $\mathbf{p}^{*}$ \\
\hline $\mathrm{DH}$ & $6.1(\min 1.1-\max 10)$ & $=0.91$ \\
$\mathrm{DH}+\mathrm{MC}$ & $6.2(\min 0.7-\max 10)$ & \\
\hline
\end{tabular}

*Mann-Whitney $U$ test was used. DH: Disc hernia; MC: Modic changes; VAS: Visual Analog Scale.

Table 3. Age, sex, VAS of distribution according to types of Modic

\begin{tabular}{lccc}
\hline & $\begin{array}{c}\text { Age } \\
\text { (Min-Max) }\end{array}$ & $\begin{array}{c}\text { Sex } \\
(\text { F-M })\end{array}$ & $\begin{array}{c}\text { VAS } \\
\text { (Min-Max) }\end{array}$ \\
\hline Modic I $(n=5)$ & $4 I(18-45)$ & $2 F-3 M$ & $4.75(0.7-7.1)$ \\
Modic 2 $(n=20)$ & $58.4(45-74)$ & IOF-IOM & $6.2(2-10)$ \\
Modic 3 $(n=3)$ & $52.6(43-61)$ & 2F-IM & $6(3.9-8.1)$ \\
\hline
\end{tabular}

VAS: Visual Analog Scale; F: Female; M: Male; Min: Minimum; Max: Maximum

scoring was $5.9(\min 0.5, \max 10)$. Gender-related median value of VAS scoring was 6.I (min 0.5, max 10) in females; in males, it was found to be $5.6(\min 0.5$, max 10$)$. In disc herniation, VAS scores were no significant difference between in patients with and without Modic changes $(p=0.91$ Mann-Whitney $U$ test) (Table 2). Age, sex, VAS of distribution according to types of Modic, the results are not statistically reliable because of the low number of Modic types (Table 3).

\section{DISCUSSION}

The prevalenve of Modic changes is escalated with the rise of the age. ${ }^{[3]}$ In our study, median age of all of the patients was 41.5 , whereas in patients with Modic changes, the median age was found 54 . The average age of the patients with Modic changes is correlated with the literature. ${ }^{[3]}$ Our patient population was younger than the other study in the literature, so the frequency of Modic changes was found to be $5.38 \%$. In the literature, there are different results for the prevalence of Modic changes. We think that the main reason for this could be the median age distribution of the populations that were being investigated. In comparison with our study, there were four studies conducted with older populations. Mann et al. ${ }^{[8]}$ reported that the Modic changes was $40.4 \%$, mostly type 2 , in a study of 
426 patients who are over 50 . Hayashi et al. ${ }^{[9]}$ reported that the median age was 49.8; the prevalance of Modic changes was 19.2\%, mostly type 2 in their study. Peterson et al. ${ }^{\left[{ }^{[0]}\right.}$ reported that the prevalace of Modic changes was 16.1\%, mostly type I in patients with a median age of 48 years. Park et al. ${ }^{[1]}$ reported that the prevalence of Modic changes was $16.9 \%$, mostly type 2 , the median age was 60 in 98 patients. Apart from these studies, Matsumoto et al. ${ }^{[2]}$ reported that the median age of the population was 39 years and the prevalence of Modic changes was $4.5 \%$, mostly type 2 , which has correlated results with our study. After considering these studies, we may claim that the prevalence of Modic changes increases with advancing age. In our study, we encountered mostly type 2 changes, whereas at least type 3 changes. These results are concordant with the prior studies of Mann, Hayashi, Matsumoto et al. Apart from these studies, Peterson et al. ${ }^{\left[{ }^{[0]}\right.}$ reported that type I changes were the most frequent type. At this point, the differences between the studies may arise from the pain period differentials for the patients. Modic changes are a time-dependant dynamic process. In our study, most of the patients had chronic pain, therefore, type 2 changes were most frequent. However, in the study of Peterson et al., ${ }^{[10]}$ there was not any data for the pain period.

C4 and C7 segments are the most mobile segments in cervical flexion and extension. ${ }^{[13]} \mathrm{C} 5-6$ and $\mathrm{C} 6-7$ cervical disc herniation. Thus, $\mathrm{C} 6$ and $\mathrm{C} 7$ radiculopathies are commonly seen because of the reason that maximum static changes stress and degeneration occurs in these segments. The least affected segment of motion is known to be the C2-3 segment. ${ }^{[14]}$ We claim that Modic changes tend to occur more frequently in the segments of C5-6 and C6-7, where there are more degenerative changes and in our study, we found that the most frequent Modic changes were in the segments of C6-7, secondly in the C5-6. Peterson et al. ${ }^{[10]}$ reported that the most affected segment was C5-6 and Park et al. ${ }^{[1]}$ reported that the most affected segment was C2-3.

It has been stated that Modic changes tend to occur with the co-existence of adjacent disc degeneration in the recent literature. ${ }^{[1,3]}$ In our study, Modic changes were noted in $24 \%$ of segments of cervical disc herniation and it was statistically significant when compared to the segments without disc herniation $(p<0.00 I)$. Furthermore, the coexistence of uncal degeneration was found to be more frequent in segments with Modic changes than in the segments without Modic changes $(p<0.001)$. These results suggest the strong evidence of relationship among Modic changes, disc herniation and uncal degeneration in the cervical spine.

The present study aims to investigate the relationship between Modic changes and cervical pain. Because of this reason, the VAS scores were compared in patients with disc herniation and in patients with the coexistence of the disc herniation and Modic changes. There was no statistically significant $(p=0.91)$. Because of the reason that in our study there was a dominance of Modic type 2 changes and chronic neck pain. In the literature, the pain was associated with Modic type I changes, which indicates early inflammation stage. ${ }^{[3,15-18]}$ Type 2 Modic changes indicate a fatty bone marrow as a means of a chronic process, this may have no relation with the pain. In our study, we have noted Modic type I changes in only five segments; we claim that it could not have affected the pain scores since it is a small-scale sample.

We have included mostly patients with chronic neck pain in our study and this may be a limitation for our study. We recommend an investigation of Modic type I changes and VAS scores in larger scales with patients of acute neck pain. Another limitation could be the improbability when determining the accuracy of VAS scores. However, in the literature, it has been demonstrated that VAS scoring is an appropriate method to assess the pain severity when compared to the other methods. While constructing the study design, some other methods have been tried as an assessment of pain severity, but VAS scoring was the most accurate and simple method when compared to the others.

It is obvious that disc herniations and uncal degeneration are related to Modic changes in the cervical spine. The neck pain was not associated with Modic changes, which may arise from the study population with mostly chronic neck pain. Recommendations were provided to investigate a new large cohort study in a patient with acute pain.

Ethics Committee Approval

Approved by the local ethics committee.

Informed Consent

Prospective study.

Peer-review

Internally peer-reviewed.

Authorship Contributions

Concept: M.E.A.; Design: M.E.A.; Supervision: E.E.E.; Fundings: E.E.E.; Materials: E.E.E.; Data: M.E.A.; Analysis: M.E.A.; Literature search: E.E.E.; Writing: M.E.A.; Critical revision: E.E.E.

Conflict of Interest

None declared.

\section{REFERENCES}

1. Modic MT, Steinberg PM, Ross JS, Masaryk TJ, Carter JR. Degenerative disk disease: assessment of changes in vertebral body marrow with MR imaging. Radiology 1988;166(1 Pt 1):193-9. [CrossRef]

2. Modic MT, Masaryk TJ, Ross JS, Carter JR. Imaging of degenerative disk disease. Radiology 1988;168:177-86. [CrossRef]

3. Rahme R, Moussa R. The modic vertebral end plate and marrow changes: pathologic significance and relation to low back pain and segmental instability of the lumbar spine. AJNR Am J Neuroradiol 2008;29:838-42. [CrossRef]

4. Braithwaite I, White J, Saifuddin A, Renton P, Taylor BA. Vertebral end-plate (Modic) changes on lumbar spine MRI: correlation with pain reproduction at lumbar discography. Eur Spine J 1998;7:363-8.

5. Karchevsky M, Schweitzer ME, Carrino JA, Zoga A, Montgomery D, 
Parker L. Reactive endplate marrow changes: a systematic morphologic and epidemiologic evaluation. Skeletal Radiol 2005;34:125-9.

6. Kjaer P, Korsholm L, Bendix T, Sorensen JS, Leboeuf-Yde C. Modic changes and their associations with clinical findings. Eur Spine J 2006;15:1312-9. [CrossRef]

7. Miyazaki M, Hong SW, YoonSH, Morishita Y, Wang JC. Reliability of a magnetic resonance imaging-based grading system for cervical intervertebral disc degeneration. J Spinal Disord Tech 2008;21:28892. [CrossRef]

8. Mann E, Peterson CK, Hodler J, Pfirrmann CW. The evolution of degenerative marrow (Modic) changes in the cervical spine in neck pain patients. Eur Spine J 2014;23:584-9. [CrossRef]

9. Hayashi T, Daubs MD, Suzuki A, Phan K, ShibaK, Wang JC. Effect of Modic changes on spinal canal stenosis and segmental motion in cervical spine. Eur Spine J 2014;23:1737-42. [CrossRef]

10. Peterson CK, Humphreys BK, Pringle TC. Prevalence of modic degenerative marrow changes in the cervical spine. J Manipulative Physiol Ther 2007;30:5-10. [CrossRef]

11. Park MS, Moon SH, Kim TH, Lee SY, Jo YG, Riew KD. Relationship between modic changes and facet joint degeneration in the cervical spine. Eur Spine J 2015;24:2999-3004. [CrossRef]

12. Matsumoto M, Okada E, Ichihara D, Chiba K, Toyama Y, Fujiwara
$\mathrm{H}$, et al. Modic changes in the cervical spine: prospective 10-year follow-up study in asymptomatic subjects. J Bone Joint Surg Br 2012;94:678-83. [CrossRef]

13. Van Mameren H, Drukker J, Sanches H, Beursgens J. Cervical spine motion in the sagittal plane (I) range of motion of actually performed movements, an X-ray cinematographic study. Eur J Morphol 1990;28:47-68.

14. Malcolm GP. Surgical disorders of the cervical spine: presentation and management of common disorders. J Neurol Neurosurg Psychiatry 2002;73:i34-41.

15. Toyone T, Takahashi K, Kitahara H, Yamagata M, Murakami M, Moriya $\mathrm{H}$. Vertebral bone-marrow changes in degenerative lumbar disc disease: an MRI study of 74 patients with low back pain. J Bone Joint Surg Br 1994;76:757-64. [CrossRef]

16. Mitra D, Cassar-Pullicino VN, McCall IW. Longitudinal study of vertebral type-1 end-plate changes on MR of the lumbar spine. Eur Radiol 2004;14:1574-81. [CrossRef]

17. Kuisma M, Karppinen J, Niinimäki J, Kurunlahti M, Haapea M, Vanharanta H, et al. A three-year follow-up of lumbar spine endplate (Modic) changes. Spine 2006;31:1714-8. [CrossRef]

18. Albert HB, Manniche C. Modic changes following lumbar disc herniation. Eur Spine J 2007;16:977-82. [CrossRef]

\section{Boyun Ağrısı, Modic değişiklikleri ve Unkal Dejenerasyon Arasındaki İlişki: MRG Çalışması}

Amaç: Bu çalışmanın amacı, boyun ağrısının Modic değişiklikler ve uncal dejenerasyon ile ilişkisini araştırmaktır. İkincil hedefimiz, servikal omurgadaki Modic değişiklikleri, disk herniasyonu, unkovertebral eklem dejenerasyonu arasındaki ilişkiyi araştırmaktır.

Gereç ve Yöntem: Boyun ağrısı olan hastalar değerlendirildi. Spinal ve servikal kitle lezyonları, spinal kırık ve servikal vertebral operasyon öyküsü olan hastaları dışlandı. İstirahatte Görsel Analog Skala (VAS) ile ağrı değerlendirmesi yapıldı. Radyolojik değerlendirme için servikal vertebral MRG ve direkt grafi kullanıldı. Bu taramalarda servikal lordoz kaybı, uncal dejenerasyon, Modic değişiklikleri ve intervertebral disk dejenerasyonu kaydedildi.

Bulgular: Disk hernisi olan hastalarda, disk hernisi olmayanlara göre Modic değişiklikleri daha sık görüldü $(p<0.00 I)$. Uncal dejenerasyon, Modic değişiklikleri gösteren hastalarda, Modic değişiklikleri göstermeyen hastalardan anlamlı olarak daha sıktı $(p<0.00 \mathrm{I})$. VAS skorları Modic değişiklikleri ile ilişkili değildi $(p=0.919)$.

Sonuç: Disk herniasyonları ve uncal dejenerasyon servikal omurgada Modic değişiklikler ile ilişkilidir. Boyun ağrısı Modic değişiklikler ile ilişkili değildi, bu durum çoğunlukla kronik boyun ağrısı olan çalışma popülasyonundan kaynaklanıyor olabilir. Araştırmamız sonucunda akut ağrısı olan hastalar da yeni büyük bir Kohort çalışmasını öneririz.

Anahtar Sözcükler: Boyun ağrısı; Modic değişiklikleri; servikal dejenerasyon; uncal dejenerasyon. 